\title{
Producing and Branding Gender in Comics: My So-Called Secret Identity and the Ambivalence of an Alternative Address
}

Bethan Jones ${ }^{1}$

Recibido: 2017-01-19

Enviado a pares: 2017-02-14
Aprobado por pares: 2017-03-13

Aceptado: 2017-04-25

DOI: 10.5294/pacla.2017.20.4.9

Para citar este artículo / to reference this article / para citar este artigo Jones, B. (2017). Producing and branding gender in comics: My so-called secret identity and the ambivalence of an alternative address. Palabra Clave 20(4), 1073-1104.

DOI: 10.5294/pacla.2017.20.4.9

\section{Abstract}

As media consumption grows increasingly niche and distribution extends further away from old network and print models (Lotz, 2007), media producers continue to hone their marketing toward ever more specific audiences. Yet, while fan-centred franchises and crowdfunding projects have garnered some scholarly attention, there has been less discussion of the ways that gender, race, and sexuality intersect with media production and marketing. This paper analyses the crowdfunded comic My So-Called Secret Identity (MSCSI) and its attempts to appeal to female comics fans. MSCSI was launched in 2013 with the aim of countering misogynistic depictions of women in comics. Created by academic Professor Will Brooker, the series focuses on Cat Daniels, an ordinary girl who becomes a superhero. I examine how the production and branding processes of the comic were used in paratexts to market MSCSI to women as specifically gendered audiences. In particular, I consider the implications of gendered (and de-gendered)

1 orcid.org/0000-0002-1626-8461. University of Huddersfield, United Kindom. bethan.jones@hud.ac.uk 
media texts on the ways that content producers imagine female audiences, as well as how they commodify and capitalize on these audiences. I argue that the comic's tagline \#smartisasuperpower, the design of the website and the deliberately female creative team function to appeal to female comic book fans and introduce new fans to the genre. I suggest, however, that the paratextual elements of MSCSI resulted in ambivalent responses from comic fans and critics, demonstrating the contradictions and difficulties of producing and branding a gendered text for a gendered audience.

\section{Keywords}

Gender; Comics; Paratexts; Fandom; Marketing (Source: Unesco Thesaurus). 


\section{Producción y branding de género en las historietas: My So-Called Secret Identity y la ambivalencia de una dirección alternativa}

\section{Resumen}

A medida que el consumo de medios se hace cada vez más especializado y la distribución se extiende más allá de los viejos modelos de impresión y de redes (Lotz, 2007), los productores de medios siguen perfeccionando su marketing para públicos cada vez más específicos. Sin embargo, aunque las franquicias enfocadas en los aficionados y los proyectos de financiación colectiva (crowdfunding) han atraído cierta atención académica, ha habido menos discusión sobre la manera en que el género, la raza y la sexualidad se cruzan con la producción y comercialización de los medios. Este artículo analiza la historieta realizada por financiación colectiva, $M y$ So-Called Secret Identity (MSCSI), y sus intentos por atraer a la afición femenina de las historietas. MSCSI fue lanzada en 2013 con el objetivo de contrarrestar las representaciones misóginas de las mujeres en las historietas. Creada por el profesor académico Will Brooker, la serie se centra en Cat Daniel, una chica normal que se convierte en una superheroína. En este artículo examino cómo los procesos de producción y branding de la historieta fueron utilizados en paratextos para comercializar MSCSI para las mujeres como audiencias específicamente de género. Particularmente, considero que las implicaciones de los textos mediáticos de género ( $y$ neutral de género) sobre las formas en que los productores de contenidos se imaginan a las audiencias femeninas, así como la manera en que mercantilizan y capitalizan sobre estas audiencias. Sostengo que el lema de la historieta, \#smartisasuperpower, el diseño de la página Web y el equipo creativo deliberadamente femenino sirven para atraer a las aficionadas de las historietas y presentarle el género a nuevos fans. Sin embargo, sugiero que los elementos paratextuales de MSCSI generaron respuestas ambivalentes de parte de los aficionados 
y los críticos de las historietas, lo que demuestra las contradicciones y dificultades de producir y crear un texto con enfoque de género para una audiencia diferenciada por género.

\section{Palabras clave}

Género; cómics; paratextos; fandom; mercadeo (Fuente: Tesauro de la Unesco). 


\section{Produção e branding de gênero nas histórias em quadrinhos: My So-Called Secret Identity e a ambivalência de uma direção alternativa}

\section{Resumo}

Na medida em que o consumo de mídia faz-se cada vez mais especializado e a distribuição se expande mais além dos velhos modelos de impressão e de redes (Lotz, 2007), os produtores de mídia continuam aperfeiçoando o seu marketing para públicos cada vez mais específicos. Contudo, mesmo que as franquias focadas nos fãs e nos projetos de financiamento coletivo (crowdfunding) têm atraído certa atenção acadêmica, tem havido menos discussão sobre a maneira como o gênero, a raça e a sexualidade se cruzam com a produção e a comercialização da mídia. Este artigo analisa a historinha realizada por financiamento coletivo, My So-Called Secret Identity (MSCSI), e suas tentativas de atrair a audiência feminina das historinhas. MSCSI foi lançada em 2013 com o objetivo de concorrer com as representações misóginas das mulheres nas historinhas. Criada pelo professor acadêmico Will Brooker, a série se foca em Cat Daniel, uma jovem normal que se transforma em super-heroína. Neste artigo examino como os processos de produção y branding da historinha foram utilizados em para textos para comercializar MSCSI para as mulheres como audiências especificamente de gênero. Particularmente, considero que as implicações dos textos mediáticos de gênero (e neutral de gênero) sobre as formas em que os produtores de conteúdos imaginam a audiência feminina, assim como também a maneira como mercantilizam e capitalizam sobre estas audiências. Argumento que o lema da historinha, \#smartisasuperpower, o desenho da página Web e a equipe criativa deliberadamente feminina servem para atrair a audiência das historinhas e apresentar o gênero a novos fãs. Contudo, sugiro que os elementos para textuais de MSCSI geraram respostas ambivalentes de parte dos fãs e dos críticos das historinhas, o que demonstra as 
contradições e dificuldades de produzir e criar um texto com enfoque de gênero para uma audiência diferenciada por gênero.

\section{Palavras-chave}

Gênero; Desenhos, Historinhas; Paratextos; Fandom; Marketing (Fonte: Tesauro da Unesco). 


\section{Introduction}

Since Rob Thomas' campaign to source funding for a new Veronica Mars film was announced in March 2013 (Thomas, 2013), crowdfunding seems to have been thrust into the spotlight. The concept of crowdfunding, where grassroots creative projects are funded by the masses through websites such as Kickstarter and Indiegogo is not new but has been steadily gaining media and scholarly attention. Daren Brabham (2013) dismisses crowdfunding as uncreative, and it only appears briefly in Henry Jenkins, Sam Ford, and Joshua Green's (2013) Spreadable Media as another potential disruption to the traditional relationship between audience and producers. Yet, with the success of the Veronica Mars Kickstarter (the 30-day campaign raised \$5.7 million, making it, at the time of its launch, the largest and most successful film project in Kickstarter's history [Bennett, Chin, \& Jones, 2015], more work has emerged, from analyses of specific crowdfunded projects to the interaction between producers and audiences, the civic and scientific possibilities opened up by crowdfunding, the role that crowdfunding platforms like Kickstarter play in discussions around fan agency and exploitation, and the ethics of crowdfunding itself (Scott, 2015a; Hills, 2015; Davies, 2015). Crowdfunding has emerged as media consumption grows increasingly niche and distribution extends further away from old network and print models to encompass online channels (Lotz 2007). Media producers continue to hone their marketing toward ever more specific markets, with the fan demographic becoming of central concern to content producers (Johnson, 2013; Proctor, 2013; Taylor, 2014). Yet, while fan-centred franchises and crowdfunding projects have garnered some scholarly attention, my interest in the ways in which the paratexts and branding of crowdfunded projects intersect with media production and marketing in today's more fan-focused media environment.

In discussing paratexts, I am drawing on Gérard Genette's (1997) concept of "a certain number of verbal or other productions [which] surround [the text] and extend it, precisely in order to present it” (p. 1). While Genette argues that these productions, which include an author's name, a title, a preface and illustrations, function as an airlock between the reader and the textual world that "is at the service of a better reception for the text and a 
more pertinent reading of it” (Genette, 1997, p. 2), Jonathan Gray (2006) believes that the paratext "does not stand between reader and text as much as it infringes upon the text, and invades its meaning-making process" ( $\mathrm{p}$. 36). He argues that industry-created paratexts, such as episode guides, cast and crew interviews, games, trailers, and DVD commentaries, inform viewers' knowledge of the text, and that they give us ways of looking at-and frames for understanding or engaging with-it (Gray, 2010). I argue that, in addition to providing the source of funding, the crowdfunding campaign functions as a paratext in its own right-demonstrating an audience desire for a text (as in the case of Veronica Mars) or that the text itself engages with specific modes of production such as fandom and the gift economy.

My So-Called Secret Identity (MSCSI) was conceived by Professor Will Brooker in late 2011 and stems from Brooker's research into Batman. Brooker had begun working on a piece about Batgirl but was frustrated with the way the character was portrayed (Brooker, 2011a, 2011b). She was klutzy and self-conscious, and even Gail Simone's reworking of her under the New 52 series was controlled by forces beyond her creative control (Simone was fired, then rehired during her tenure writing Batgirl). Brooker thus envisioned My So-Called Secret Identity as a kind of Batgirl fanfiction, in which he could right the wrongs he felt were being done to the character (Sneddon, 2013). The original idea was to write a few pages of scripts, commission some artwork and post it to the Mindless Ones website as part of a series of posts Brooker had already begun. However, as the idea progressed, Brooker decided to scrap the specifically Batgirl concept, kept the basic template of a $\mathrm{PhD}$ student in a 1990s American city full of larger-than-life costumed characters, and build it up in a different way (Brooker, 2011c). My So-Called Secret Identity thus focusses on Catherine Abigail Daniels, a PhD student in Gloria City. Gloria City itself is full of superheroes, though Brooker notes they are superheroes who never do anything heroic and "we don't know if they actually have any powers, or whether it's all stunts, hydraulics, controlled explosions and dry ice" (Ford, 2014, n.p.). Cat has no superpowers herself and has learned to keep her head down, to never boast or show that she was different, but by the end of the first issue we see her reveal that she does have a kind of power: She is extremely intelligent, with the abili- 
ty to make connections and absorb copious amounts of information. The first issue ends with Cat deciding that, if nobody is going to take her seriously as Catherine Abigail Daniels, she will get a costume and a logo and play the superhero game herself. The first issue was funded by Brooker and published online at a dedicated website managed by Lindsay Searles. The site included a reviews section, a lookbook (an interactive webpage similar to a scrapbook) featuring behind the scenes information about the comic and a donate button. Issue 1 remained online for free while readers were able to donate to the project to fund subsequent issues. A percentage of the proceeds went to charities supporting women's causes. A Kickstarter campaign was launched in June 2014 to raise money to fund Issue 5 of Volume 1 and publish a complete, high quality, print edition of Issues 1-5. Another Kickstarter campaign was subsequently launched to publish a 120-page edition of Volume 2, and as of March 2017 the comic is available in its entirety online for free, with remaining copies being sold through Rape Crisis, and all profits going to them.

My interest in this paper, however, is less in the process of crowdfunding the comic, and more in how the comic's status as a crowdfunded project framed the comic and contributed to its paratextual positioning as a feminist work. My So-Called Secret Identity attempted to appeal to female comic books fans and non-fans through both its production and branding processes, and its position as a crowdfunded text was used to discursively position the comic as a variation on female fan communities in which the gift economy plays an important role (Hellekson \& Busse, 2006). I examine how the comic's creators framed MSCSI discursively through paratexts as a comic that would "change your view on women in comics" (Granshaw, 2014, n.p.) and analyse Brooker's statements as a form of editorialising paratext that seek to shape the text's audience. I thus consider the implications of gendered (and de-gendered) media texts on the ways that content producers imagine female audiences, as well as how they commodify and capitalize on these audiences. I argue that the comic's tagline \#smartisasuperpower, the design of the website and the deliberately female creative team function to appeal to female comic book fans and introduce new fans to the genre, yet I also suggest that the discursive construction of MSCSI 
by the comic's core team — headed by Brooker-created tensions among some female comic fans familiar with existing online feminist comics. This ambivalent response demonstrates the contradictions and difficulties of producing and branding a gendered text for a gendered audience.

Before I begin my analysis, however, I want to declare my interest in My So-Called Secret Identity. Brooker is a friend and colleague, and approached me to be part of the supporting team behind the comic back in 2012. Consequently, I set up and ran the My So-Called Secret Identity message boards and advised Brooker and the team on other aspects of the comic. I agreed to help, partly because Brooker is a friend, but more importantly because I thought $M y$ So-Called Secret Identity was doing something different. While sharing his reasons for writing the comic, Brooker discussed his experience of walking into a comic shop just after the release of the New 52 and being stared at by half a dozen young lads. He said "not only was I in this dingy shop that felt like a teenage boy's bedroom, but most of the comics on the racks offered glossy, cheesecake pin-ups of women. It made me feel disappointed about what had become the norm in superhero comics, and frustrated that they couldn't be different" (Langsdale, 2013a, para. 12). Like Brooker, I have felt uncomfortable in comic shops and have also become increasingly dissatisfied with the way women in comics are depicted. Therefore, My So-Called Secret Identity felt like a chance to make a real difference to the representation of women in comics and to women who want to read them. My involvement with the comic, then, positions me as an aca-fan - that is, according to Jason Mittell (2010), "a hybrid of academic and fan critics that acknowledges and interweaves both intellectual and emotional cultural engagements" (para. 14). This position affords me a unique perspective on My So-Called Secret Identity, both in relation to its marketing and in analyses of what the comic attempts to do and how those attempts are perceived.

Regarding methodology, the quotes analysed in this essay were collected from a range of online sources including social media, discussion boards and blogs. Each of these posts were in publicly accessible archives - that is, they were visible to anyone viewing those sites and did not require users to 
log in in order to read the post. Posters are thus aware that their posts will be viewable to all. Furthermore, these posters make "straightforward declarations of textual (anti-)fandom, in which fans talk about a text and their attitude towards it [which] need not necessarily require researchers to obtain permission to quote" (Jones 2016, p. 292; emphasis in the original). Therefore, and in line with the Association of Internet Researchers guidelines concerning privacy and harm, no ethical issues arose from the use of these sources (Markham \& Buchanan, 2012).

\section{(Para)Textually Branding My So-Called Secret Identity}

Much male, geek discourse frames women in geek culture as inferior, if not invisible, to men (Scott, 2013). The concept of the fake geek girl has been circulating in geek spaces for some time; for example, Tony Harris-comic artist and creator of Starman - posted a diatribe to his Facebook wall in which he decried female cosplayers as imposters who "DONT KNOW SHIT ABOUT COMICS, BEYOND WHATEVER GOOGLE IMAGE SEARCH [they] DID TO GET REF ON THE MOST MAINSTREAM CHARACTER WITH THE MOST REVEALING COSTUME EVER” and who prey on innocent comic-loving guys while deluding themselves that they are pretty (as quoted in Dickens, 2012). Similarly, violence including rape and death threats was directed towards Anita Sarkeesian following her Tropes vs Women Kickstarter campaign to highlight sexism in gaming. As a result of the Kickstarter, Sarkeesian was sent rape and death threats, had her home address and various other personal information posted online, and speaking events she was due to attend were cancelled after a man threatened to shoot her there (Parkin, 2014). In contrast, My So-Called Secret Identity does something different by highlighting its female creative team. The creators section of the website highlights Brooker, Shore and Zaidan as the creators, and the Team Cat section, which names those who have worked on the comic in some capacity, is predominantly female. The role that women played in the project was given prominence in reviews, interviews and the Kickstarter itself, and functions as one of the important discourses surrounding the comic. Jonathan Gray (2010) argues that "Hype is advertising that goes 'over' and 'beyond' an accepted norm, estab- 
lishing heightened presence, often for a brief, unsustainable period of time" (p. 5). Matt Hills (2015) further notes that hype is not seamless: "A range of different paratextual voices can instead overlap, generating harmonies in some cases, but clashing discordantly in others" (p. 28). The bulk of press discourse surrounding MSCSI, in which Brooker and other creators were quoted, was, however, harmonious. Publications such as The Daily Dot, Sequart and The Guardian highlighted the creative team as a driving factor in not only MSCSI, but in changing the industry. Discussing the reason for having a female production team, Brooker (2011c) writes:

\begin{abstract}
I felt it would be an interesting idea to reverse the usual industry ratios and have a predominantly-female creative team involved. Most of the artists contributing to this project are women. I've also asked some feminist comic book critics and commentators I admire to give their feedback and help shape the script. (para. 21)
\end{abstract}

And variations on this quote are replicated across different outlets. The female team behind My So-Called Secret Identity is typically discussed in positive ways-in their review of the comic Geeked Magazine wrote "I'M SORRY I KEEP SHOUTING BUT I'M SO EXCITED!!! A comic book about an awesome-brainy-reader-kickass-redhead-girl, made BY (mostly) women (and one totally righteous dude), and sold to support a women's charity?! *head explodes" (Langsdale, 2013b, para. 14). In addition, Ms. Magazine highlights the different skills and knowledge brought to the comic, in particular noting that not all of the team are comic book geeks: Suze Shore, for example, knew little about superhero comics before joining the My So-Called Secret Identity team but was brought on board because of her artistic ability rather than any knowledge or cultural capital in relation to comics or superheroes (Dove-Viebahn, 2013).

Discussing promotional material such as posters and the website, Gray (2010) sees them as useful precursors (and guides) to the central text. Barbara Klinger (1989), however, argues that these materials are not "primarily interested with producing coherent interpretations" but "produce multiple avenues of access to the text $[\ldots]$ in order to maximise its audience" (pp. 9-10). Thus, framing the central role of the female creative team in paratextual discourse in a range of outlets, from mainstream press to feminist-ori- 
ented websites, allows multiple audiences to access the comic, in addition to signalling to those audiences how they should interpret it. This dual approach of maximisation and interpretation is furthered in the website itself. Explaining the design of the website, Brooker (2013) says:

\begin{abstract}
it does look usefully different from the dominant artistic style of superhero comics, which are currently attempting a kind of videogame/ cinematic mode, with digital colours, lens flare and effects. We wanted My So-Called Secret Identity to look immediately different from something like the New 52's Red Hood and the Outlaws. We've done that in a range of ways - by designing the website more like a fashion magazine or blog than a comic book, by employing watercolours instead of glossy digital effects, and by drawing on this particular scrapbook style, which thanks to Pinterest I think does currently connote a text for female readers, and which we hope will appeal to people who don't usually pick up a superhero story. (as cited in Jones \& Bennett, 2013, p. 345)
\end{abstract}

By deliberately moving away from the superhero aesthetic, the website differentiates itself and attempts to appeal to a different audience than those who may balk at work by Marvel or DC. In addition to paratextual discourse, which signposts audiences to the website, the site itself functions as another avenue of access, but also as a signifier as to how audiences should interpret the comic. The lookbook, in particular, paratextually brands the comic as appealing to a different segment of the audiences.

The lookbook is a section of the website designed to function as a scrapbook and featuring behind the scenes concepts and sketches (see Figure 1). As well as functioning as a scrapbook, the lookbook is designed to mimic one-its title is picked out in different styles and fabric, and paperclips hold pieces of paper inside it, while sections of the lookbook can be enlarged by clicking on them-on page one, for example, the photobooth strip can be enlarged, and the pages can be turned so the viewer can look at other issues in the volume. In his review of My So-Called Secret Identity, Mike Allwood (2011) describes the lookbook as "like the extras on a DVD", which further draws comparisons to the paratextual branding of the comic. Gray (2010) notes that many of the bonus materials included in DVD editions, "such as 'restored' scenes, interviews 
with creative personnel, commentary tracks, production stills, and making-of documentaries, stamp their texts with authenticity, insisting on that text's claim to the status of great art" (p. 83) and thus laying discursive claim to the real text. The lookbook functions in a similar way, both textually and aesthetically.

\section{Figure 1. Lookbook}

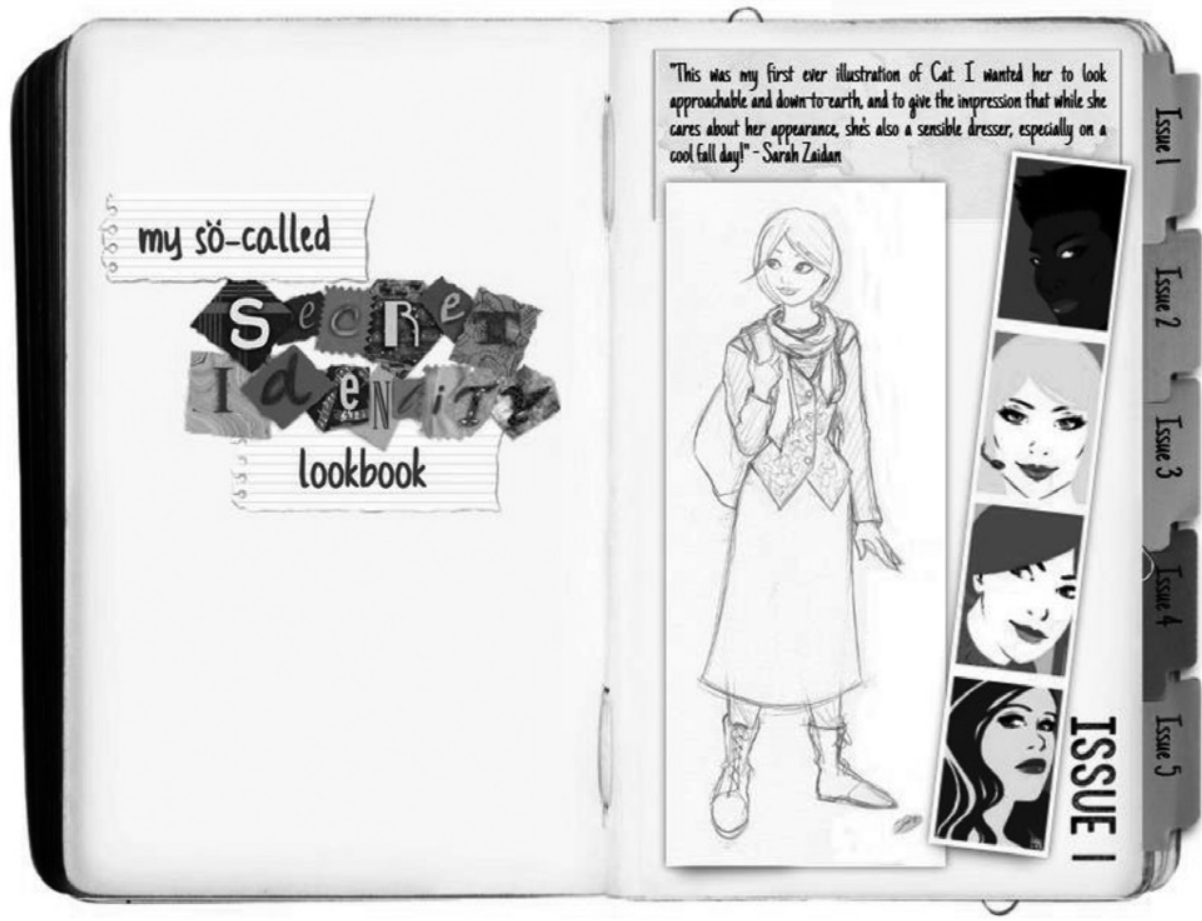

Source: Lookbook (n.d.)

I would further suggest, however, that there are also close correlations to be drawn between the lookbook and scrapbooking as feminine creative work. Brooker (2013) likens the lookbook to Pinterest, and argues that this "distinguishes the project helpfully from mainstream superhero comics for teenage boys and young men. A scrapbook aesthetic also works to undermine any sense of a single, restrictive look for the characters - instead, we have various interpretations of Cat and the supporting cast-and gently subverts mainstream ideals of female representation in comics" (as cited in Roddy, Lavigne, \& Scott, 2013, para 5.4). Much as Jane Arthurs (2003) 
argues that the novelty of Sex and the City "lies in the migration of a woman-centred and explicit sexual discourse into television drama [and] [i] ts distinctive appeal arises from its ability to 're-mediate' the familiar forms of the television sitcom and the glossy women's magazine” (p. 83), MSCSI's novelty lay in its migrations of a woman-centred and intelligent discourse into superhero comics, with its appeal coming from its re-mediation of superhero comics and women's glossy magazines. Of course, there are issues with aligning female readers with fashion, blogs and scrapbooks. Scott (2015b) points out that Pinterest reinforces gender ideologies through shopping and crafting, and some critiques of My So-Called Secret Identity castigate the overtly feminine approach. In her analysis of beauty advertisements, Lazar (2009) argues that a postfeminist feminine identity emerges, discursively formed of three themes including a reclamation of, and rejoicing in, feminine stereotypes. She states that "contemporary media represent women as assertive, in control and autonomous, having a strong public presence, while confidently embracing feminine practices" (Lazar, 2009, p. 371) and I would argue that the lookbook section of the MSCSI website embraces this representation.

This double entanglement (McRobbie, 2007) of normative and newer imaginings of femininity is thus evident in the text and paratexts of MSCSI, evidencing an "immensely complex and contradictory discursive space that assimilates feminist signifiers as well as feminists' repudiations of normative patriarchal practices" (Lazar, 2009 p. 373). No further is this evident, perhaps, than in the comic's tagline-smart is a super power (see Figure 2). Used as the hashtag on the bulk of the tweets about the comic, as well as the two Kickstarter campaign videos and interviews with Brooker, Zaidan, and Shore, the motto serves to empower female readers who themselves are smart, but are perhaps afraid to - or have been told that they shouldn'tshow it. Brooker (2013) notes that "The single page that gets the most airplay is the one I described in the script as the 'hero shot', where she looks up at us from her library book and says 'I'm really, really, goddamn smart.' That's the panel and the line that's repeated most in reviews, and which came to epitomize the whole first issue" (as cited in Helvie 2013, para. 5). 


\section{Figure 2. My So-called Secret Identity Issue 1, Page 13}

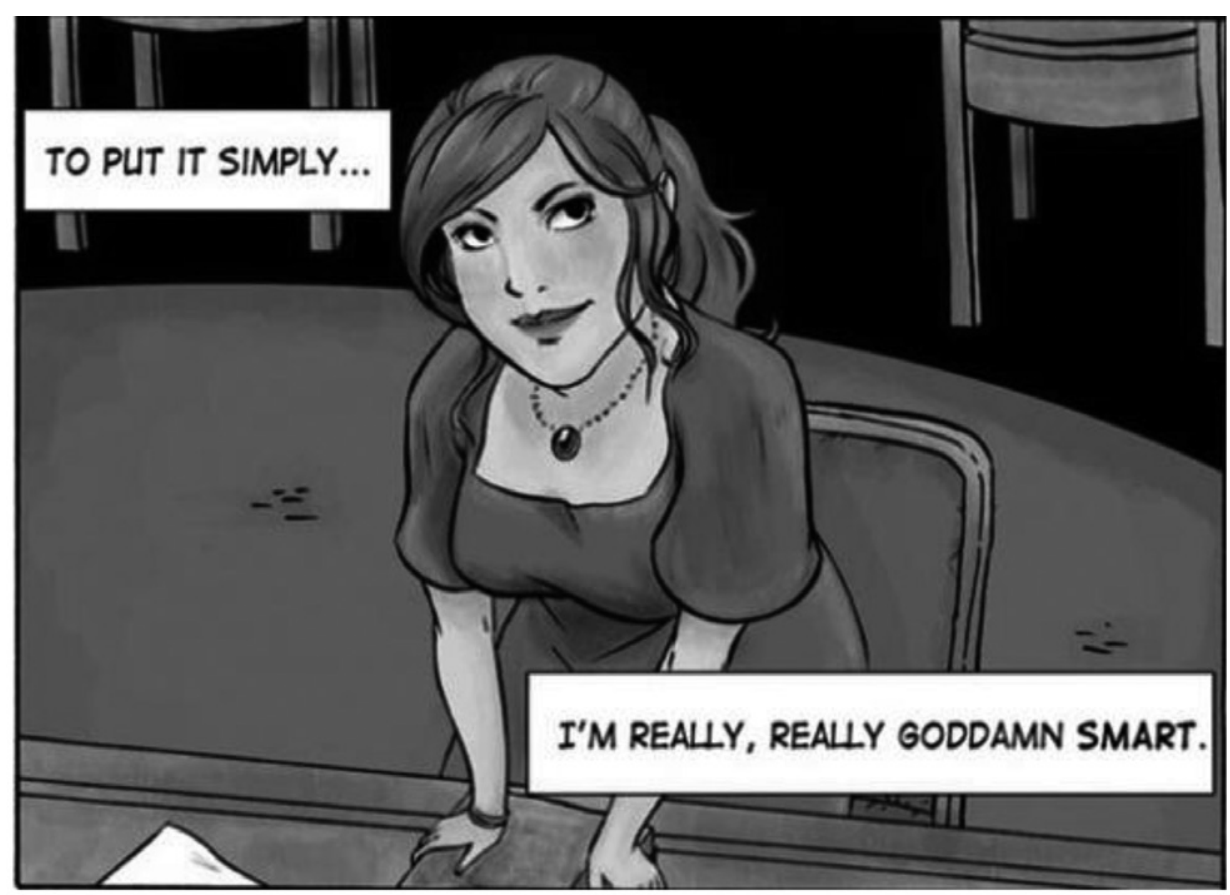

Brooker's reference to Cat's acknowledgement that she is smart as a hero shot refutes the traditional, masculine, hero shot of superhero comics, but the tagline "smart is a superpower" also stands in opposition to the oft-quoted "smart is sexy". I would argue that "smart is a superpower" becomes explicitly feminist in the context of the comic, while also commenting on wider discourses around women in geek culture-for example, the fake geek girl in contrast to the acceptable smart and sexy geek girl, and the incredibly smart but not so pretty geek girl.

Although the idea of smart superheroes is not new-Bruce Wayne and Tony Stark, for example, are highly intelligent-, having a female superhero that is defined solely by her intelligence is. Referring to Batgirl, and the original impetus for My So-Called Secret Identity, Brooker (2011c) notes how Barbara Gordon was nothing like the $\mathrm{PhD}$ students he met at their induction in October 2011. Indeed, Barbara herself views her intelli- 
gence as a way for people to put her down (she is just a female brain) and calls her attendance in costume at the policeman's ball the highlight of her life-above and beyond obtaining her $\mathrm{PhD}$. Smart as a superpower subverts that and tells the reader that being smart is good, especially if you are female. Many readers of the comic felt those lines speak to them: online publisher Fanbase Press (formerly Fanboy Comics) wrote in 2013 that it serves as an important message to any readers because being intelligent is nothing to be ashamed of. In addition, the clips of fans saying the phrase sent into the comic's Facebook page include several young girls, some in cosplay as Cat, claiming the "smart is a superpower" tagline for themselves.

So far, then, I have given a brief overview of three of the key features of the Kickstarter campaign to market My So-Called Secret Identity to a female audience. Each of these is important-as are the publications which highlighted the comic: The Daily Dot, The Mary Sue, and Geeked Magazine are all organisations which have an interest in feminism and comics, and which comment on the way women are treated in popular culture. By targeting these venues for My So-Called Secret Identity, Brooker was able to target the comic at an intended following, as well as being supported by magazines high in feminist, geeky cultural capital.

\section{Continuing the Gift Economy: Female Fan Practices and the Interpretive Community}

What I want to focus on now, however, is the way My So-Called Secret Identity frames itself as a positive intervention, rather than a negative defence. This is another area foregrounded in interviews with Brooker (and I will discuss the prominence of Brooker's voice shortly). Brooker is known for being an academic and dealing predominantly with theory rather than practice, thus creating a comic book from the ground up rather than simply critiquing representations in academic work functioned to make the work accessible to a wider public, as well as defending against accusations that he couldn't do it better himself. In an interview for the journal Participations, Brooker wrote: "it's a way of putting criticism and research into practice (doing differently, rather than just pointing out what other people are doing wrong) - it involves ethics (trying to live up to your political aims 
with a commercial product in a marketplace)" (as cited in Jones \& Bennett, 2013, p. 336). There are also comments on issues of gender in comics hidden within My So-Called Secret Identity, which are also the rationale for the comic itself. In Dahlia's discussion with Cat about her crime-fighting, she notes how many women who have done was Cat is doing wind up disabled or dead-Barbara Gordon being one of them. This intertextuality thus speaks to fans of the superhero genre and also places Brooker as an insider in comics fandom, now aware of the issues inherent in the superhero genre and therefore in a position to address them.

My So-Called Secret Identity positions itself as a positive example of a female-centred superhero comic, then, not only in its premise but in its execution. Discussing the charitable comic anthology Womanthology, Suzanne Scott (2013) categorizes it as "an industrially transformative work, one that strives to effect the same change on the comic book industry that a fan might on a media property, bending it to align with textually unacknowledged identities and desires and wielding it as a mode of critical commentary" (para. 5.2). I would suggest we can we position My So-Called Secret Identity in the same way: As I have already noted, the team behind the comic are predominantly female, and this serves to demonstrate that women can go out there and do the same work in comics as men. Examining the section of the lookbook for Issue 4 (Figure 3), for example, the audience is told that the artwork for Kyla Flyte, one of Gloria City's superheroes, was created by Ursula Dorada and Suze Shore, speaking to the collaborative nature of the project and echoing a fannish mode of practice. Henry Jenkins (1992) notes that "[f] an writing builds upon the interpretive practices of the fan community, taking the collective meta-text as the base from which to generate a wide range of media-related stories" (p. 156) and the genesis of My So-Called Secret Identity replicates this mode of production. Brooker writes openly about using Batgirl as a framework for Cat, using a variety of comics as the base from which MSCSI was generated. This interpretive, collaborative mode of production was also replicated through MSCSI's growth, with new writers, vidders and artists being brought into the team, either through invitation by Brooker or one of the other artists, or by contacting the team to ask about characters or storylines. For instance, in $M y$ 
So-Called Secret Identity Backstory, Brooker (2017) notes that Angel Kumar wrote to him through our Facebook to ask if he'd considered including a British Asian character in Volume 2; Brooker asked if she would like to write the story, and Kumar accepted.

\section{Figure 3. Lookbook}

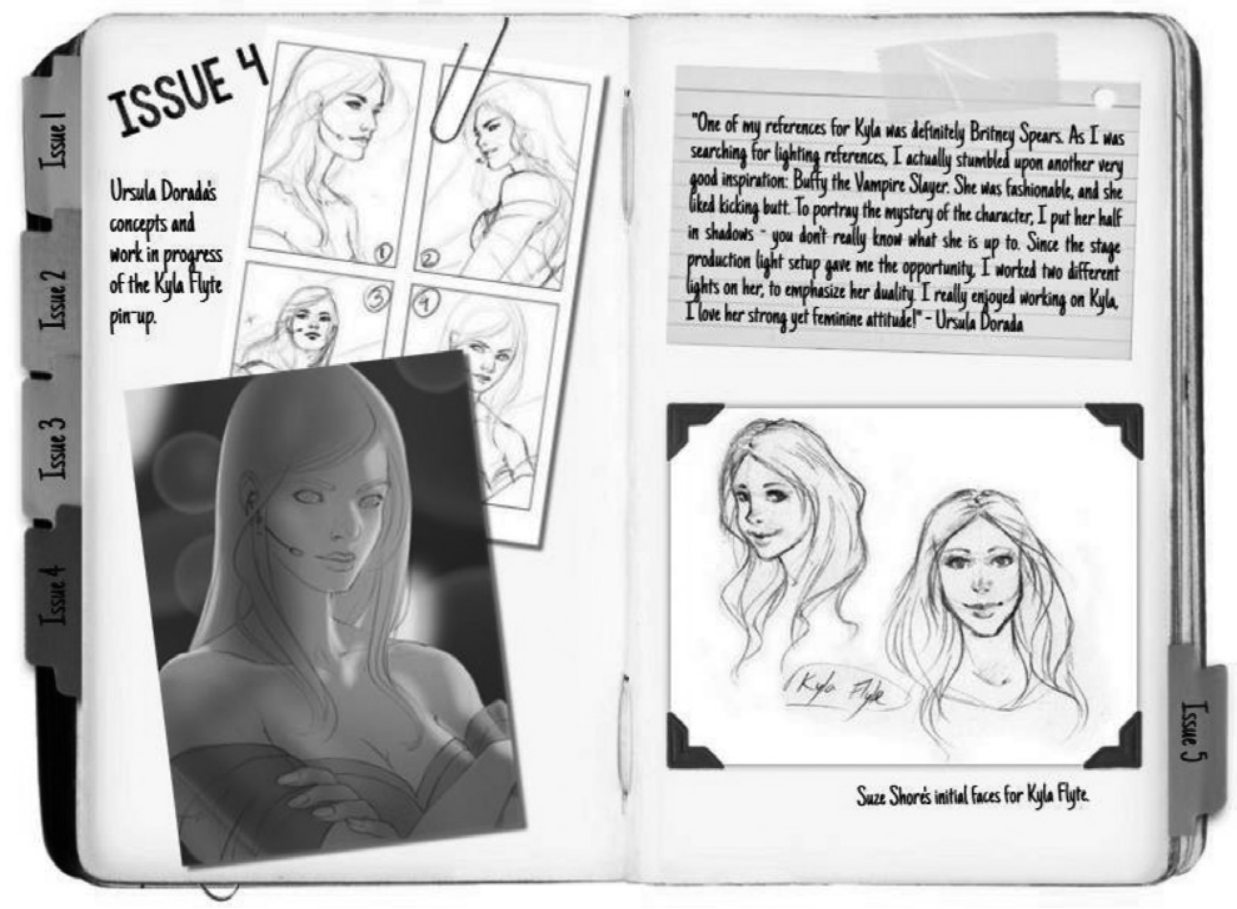

Source: Lookbook (n.d.)

More fundamentally, however, is the similarity to (predominantly) female fan practices in the design of the crowdfunding campaign. Brooker writes that his approach was informed by what he knew about fan communities, specifically female fan communities, and even more specifically, the communities discussed by Karen Hellekson and Kristina Busse in their book, Fan Communities in the Age of the Internet. Hellekson and Busse (2006) explain the process of gift economy, where one fan does something for another without any fixed arrangement or desire for reward (p. 5) and Brooker argues that this was a deliberate approach taken in the development of the comic: 
Every artist was paid on commission, at a rate they suggested. Everyone who contributed was credited as part of "Team Cat." It still felt like we were doing things a little differently, and a little better, compared to the mainstream comics industry — or at least, to what I knew of it $[\ldots]$ In fact, we barely had contracts at all, and we seemed to manage without them. I was proud of that. People were working and being paid by a system of trust. I reached out to other artists, from small-press to veteran professionals. In each case, we gave them credit and promoted their work, and in turn, they boosted our signal and did us favours without being asked. [...] In many of these cases, it doesn't feel like business, over and done with an exchange of payment and a handshake; it feels like a longer, mutually-beneficial, creative relationship. (Brooker, 2015, pp. 234-236)

The approach Brooker took was not only markedly different from that by many other mainstream presses, it also featured heavily in the marketing of the campaign. Fan communities, particularly those in which fanworks like fan fiction and fan art circulate, are predominantly comprised of female fans who put into practice the gift economy. While fandom is by no means exclusively female, the notion of the gift economy is often gendered as such, and its importance to My So-Called Secret Identity underlines the comic's feminism. As Jones (2014) notes, fans

beta read each other's work, correspond with readers and other writers in mailing lists and discussion forums, respond to challenge communities, upload fan art as bases for icons, create videos based on other fans' song requests, meet in conventions, and share advice on cosplaying, among other activities. (n.p.)

These activities to foster a sense of community within fandom and form part of the gift economy (Hyde, 1983).

By drawing on this approach to develop My So-Called Secret Identi$t y$, and by making that approach transparent in interviews about the comic, Brooker was able to capitalise on a predominantly female approach to business. This approach was certainly heralded by many in the mainstream as a new way to create a comic, although it—and the comic's content-was not new to those already invested in fannish communities or familiar with female-led webcomics. Hyde (1983) suggests that gift economies are dis- 
tinguishable from commodity culture because of their ability to establish a relationship between the person giving the gift and the person receiving it, which creates a communal bond founded on a sense of obligation and reciprocity (Scott, 2010). Yet given MSCSI's status as a crowdfunded campaign, the idea of the gift economy begins to unravel. As Scott (2010) notes, fans do occasionally finance the creative labour but " $[t]$ hese fannish exchanges of capital can provoke conflicts within fan communities, with some arguing for a need to protect fandom's longstanding gift economy (Hellekson, 2009), and others suggesting that fans must find a way to be financially compensated for their creative labor (De Kosnik, 2009)" (2015a, pp. 169170). Fan investments in crowdfunded media projects are similarly fraught with conflicts of opinion: "some choosing to view these donations as simply pre-paying for a product fans already desire (Mittell, 2013), and others suggesting that offloading the financial burden onto fans doesn't offer a fair return on their investment" (Scott, 2015b, p. 170). Brooker's call to female fan communities thus discursively positions MSCSI within a female, fannish history yet a deeper analysis of this claim uncovers contradictions and complications.

\section{Editorialising Paratexts and the Role of the Author}

Brooker's voice is prominent in discourse surrounding MSCSI. As I have already noted, quotes ascribed to him feature in interviews and articles on a variety of press outlets, and the lookbook contains further background information on the comic and its production processes, authored by Brooker. Indeed, throughout the course of this article I have cited Brooker far more than I have quoted he others involved. The role of the author here functions as what Mittell refers to as orienting paratexts. These, he suggests, are

distinct from transmedia paratexts that explicitly strive to continue their storyworlds across platforms [...]. Instead, such orienting practices exist outside the diegetic storyworld, providing a perspective for viewers to help make sense of a narrative world by looking at it from a distance. (Mittell, 2014 p. 165)

Mittell argues that there are four basic storytelling facets that might require orientation: time, events, characters, and space, and that each of these 
may be oriented through one of three practices: recapitulation, analysis, or expansion. I would argue, however, that context also requires orientation, beyond the diegesis, and Brooker's statements function as a contextual orientation, or an editorialising paratext. Brooker's voice remains the authorial voice of the comic given his prominence in both the academy and in articles about the comic, but he also takes on an editorialization function, where:

\begin{abstract}
What becomes important is not the unity of a text produced by one person but the ensemble of relationships that this content maintains with other contents. And these relationships are, at the same time, what determines the existence of a piece of content. It is the whole series of relationships and links that make the content accessible, visible and therefore actually existing. (Vitali-Rosati, 2014, p. 120)
\end{abstract}

Brooker is aware of the role he has played in the comic's branding and acknowledges the easy ride that My So-Called Secret Identity has had when compared to other female-run campaigns, and the role that his perceived gender plays in that, writing:

I do think that there's a tendency for people to feel grateful and relieved when a man says or does anything remotely feminist-or even when he says or does something which is half-decent and not misogynist-and that's not how it should be, but I suspect that might be the case with us and it might have helped us out [...] I'm not entirely comfortable with that situation, because obviously I am unhappy that female-fronted projects are so often subject to hostility, but I think to an extent we used it as a strategy-putting me forward as the front-person - and if it's a means to an end and it enables us to achieve positive results, then I can live with it for now. (Brooker, as cited by Sneddon, 2013, n.p)

The positive results certainly came in specialist and mainstream responses to My So-Called Secret Identity. Sites including The Guardian and the Times Higher Education supplement featured articles on the comic and its attempt to feature more women in the superhero genre. Where criticism did come, however, was from female readers already familiar with comics. In her review of the comic, blogger theviciouspixie wrote:

I am delighted that Brooker has noticed the problems inherent in comics' relationship with gender, and that he has chosen to do 
something about it. But in making these statements, I feel he's acting like that guy who identifies as a feminist and participates in feminist discussions, but mansplains over women when they're contributing their lived experience. What he's doing it great, but it's not unique. Judging by the article, he's either chosen not to talk about the excellent existing body of work by female creators in favour of promoting his own series, or he's not searched hard enough in his own back yard to find it there. (2013, para. 15)

Rather than seeing Brooker's comments as an editorialising paratext, then, theviciouspixie regards them - and by extension Brooker-as an unnecessary intermediary who draws attention away from the work itself. Indeed, most of the criticisms aimed at the comic were targeted at Brooker rather than the comic's content or its aim at creating something for women. Interestingly, many of the readers referred explicitly to the marketing of the comic and Brooker's background as an academic in their critiques:

\begin{abstract}
Mr. Brooker is cleverly marketing his comic as "the only comic for girls" and making a huge deal out of it. It's a bit as if he thinks he reinvented the wheel. [...] The website describes his as an "international academic expert on media and popular narrative", but I really wonder if any of his knowledge extends into the comic scene. Or, if it does, I wonder why he chooses to ignore a large part of the industries. My guess is that he noticed that there is in-fact [sic] a large female audience out there, who think that the whole over-sexualization is a bit of a (sad-gotten out of hand kind of) joke (with things like the hawk-eye initiative getting massive exposure) and he's simply using our "anger" about this for marketing purpose [sic]. (ElsaKroese2013, para. 4-5)
\end{abstract}

The discursive construction of the comic's audience through paratexts thus worked in targeting female readers who may have been unfamiliar with superhero comics (except through paratexts highlighting their sexism), but failed when faced with women who already read comics. Brooker's position as an academic, which also functioned as a paratexts, was similarly unimpressive to these readers:

I feel like the academic world is about 20 years behind the actual world, especially when it comes to modern media, and internet media in particular. People/university teachers/the like with job titles like "Media expert" or how they describe this author usually says to me 
they spend time "studying" the internet 10 years ago and think they are experts when they haven't caught on to any changes that happened in recent times. [...] All of my favorite webcomics (and this is a coincidence, I had to sit and think about it for a minute) are written by women, and that's not why I read them. I read them because they're good (like Spindrift!). There are plenty of comics "for girls" out there, by authors both male and female, and this guy does sound like he's just using a cheap marketing gimmic [sic] to sell something that otherwise didn't catch anyone's attention. (artisteri, 2013, para. 1-2)

Fundamentally, critiques such as these have been levelled at the fact that Brooker is speaking for women rather than at Brooker himself. Indeed, many commentators note that they "can see what he is trying to do" but question whether it is Brooker's place, as a male academic, to do that work rather than seeking out existing female-led comics and promoting those (theviciouspixie, 2013; Kroese, 2013). And this is perhaps the biggest issue with the comic and its attempts to change the perception of women in the superhero genre-it was conceived of, created by and overseen by a man, and a man who possesses significant amounts of cultural capital. Nevertheless, the critiques levelled at Brooker have been far less personal and violent than those aimed at Anita Sarkeesian, Zoe Quinn or the female cast of Ghostbusters. Indeed, Brooker's 2015 David Bowie project, where he spent a year experiencing the star's life at different points through his year career, received more criticism: A The Guardian article on the project generating six pages of predominantly negative comments, compared to the The Guardian article on My So-Called Secret Identity receiving three (Gani, 2015; Flood, 2013).

\section{Conclusion}

Throughout this article I have addressed the production and marketing of the crowdfunded comic My So-Called Secret Identity through an analysis of paratextual discourse. I have outlined how paratexts including the website, the comic's tagline and authorial statements from the comic's creator functioned to brand the comic and construct its audience as a specifically gendered one. At the time of writing this article, Volume 2 of My So-Called Secret Identity has been printed, the comic in its entirety has been published online for free, and print copies are being sold through Rape Cri- 
sis, which keeps all of the profits. Updates posted to the comic's Facebook page during the production of Volume 2 continued to highlight the comic's focus on female characters and its predominantly female creative team. These posts, however, generated fewer responses that those posted when the comic was starting out. My So-Called Secret Identity's grounding in positive change, rather than negative defence, initially positioned it as an alternative to other comics instead of as a competitor or interloper. However, little has changed in the wider social or industrial context in the years since the comic was launched, suggesting that, perhaps, attempts to appeal to such a wide audience have not quite worked.

Created in direct response to the cheesecake artwork of many superhero comics, the creative team, storyline, and web design were planned and implemented to speak to a female audience, attempting to appeal both to existing comic book fans and readers new to the medium and genre. Indeed, when compared to critiques like Anita Sarkeesian's 2012 (also crowdfunded) “Tropes vs. Women in Video Games," however, My So-Called Secret Identity comes across as a gentler call to action. With its intertextual nature-drawing particularly on Batman as well as other superheroes-My So-Called Secret Identity can be read alongside rather than instead of. This is not to say that gamers can't watch Tropes vs. Women and then play Grand Theft Auto-it is entirely possible to be a fan of problematic things while recognising what they are problematic for, but in a culture where women should still, apparently, be seen and not heard, My So-Called Secret Identity's alternative address goes some way to quelling the criticism that would be aimed at it were it helmed entirely by women.

But questions still remain around whether My So-Called Secret Identity's broad acceptance by critics, especially, is contingent upon a man being the spokesperson for, and originator of, the comic. Would My So-Called Secret Identity have been welcomed as much if Shore or Zaidan-or any other woman-had been used as the face of the comic? And what does this say about the presence of and attitudes to women in the comics industry? As I have demonstrated in this article, the comic and its paratexts inhabit contradictions around normative femininity while embracing what may 
still be considered non-normative behaviours. MSCSI can thus be understood both as progressive and as conservative, depending on interlocutor and a nuanced understanding of content.

\section{References}

Alloway, S. W. (2013, June 57). 'My So-Called Secret Identity \#1-2:' Advance comic book review. Retrieved from http://www.fanbasepress.com/ index.php/blogs/steven-w-alloway/item/2461-my-so-called-secret-identity-1-2-advance-comic-book-review

artisteri. (2013, February 24). Re: Rant about 'My So-Called Secret Identity' [Comment on a DeviantArt entry]. Retrieved from http:// comments.deviantart.com/1/355940165/2955461536

Arthurs, J. (2003). Sex and the City and consumer culture: Remediating postfeminist drama. Feminist Media Studies, 3(1), 83-98.

Bennett, L., Chin, B., \& Jones, B. (2015). Crowdfunding: A New Media \& Society special issue. New Media \& Society, 17(2), 141-148.

Brabham, D. C. (2013). Crowdsourcing: A model for leveraging online communities. In A. Delwiche, \& J. J. Henderson (Eds.), The participatory cultures handbook (pp. 120-129). New York, NY: Routledge.

Brooker, W. (2011a, June 8). Batgirl's last dance: The brave and the bold \#33. Retrieved from http://mindlessones.com/2011/06/08/batgirl-dance/

Brooker, W. (2011b, October 19). Meanwhile in 1971: A life in continuity. http://mindlessones.com/2011/10/19/meanwhile-in-1971-alife-in-continuity/

Brooker, W. (2011c, September 9). From killer moth to killing joke: Batgirl, a life in pictures. Retrieved from http://mindlessones.com/2011/11/09/ from-killer-moth-to-killing-joke-batgirl-a-life-in-pictures 
Brooker, W. (2015). Building a better kickstarter: Crowdfunding My SoCalled Secret Identity. In L. Bennett, B. Chin, \& B. Jones (Eds.), Crowdfunding the future: Media industries, ethics, and digital society (pp. 233-238). Oxford: Peter Lang.

Davies, R. (2015). Four civic roles for crowdfunding. In L. Bennett, B. Chin, \& B. Jones (Eds.), Crowdfunding the future: Media industries, ethics, and digital society (pp. 83-98). Oxford: Peter Lang.

De Kosnik, A. (2009). Should fan fiction be free? Cinema Journal, 48(4), 118-24. http://dx.doi.org/10.1353/cj.0.0144.

Dickens, D. (2012, November 13). Comic book illustrator Tony Harris hates women (cosplayers). Retrieved from https://www.buzzfeed.com/ donnad/comic-book-illustrator-tony-harris-hates-women-co

Dove-Viebahn, A. (2013, February 25). It's a bird! It's a plane! No, it's a feminist superhero! Retrieved from http://msmagazine.com/ blog/2013/02/25/its-a-bird-its-a-plane-no-its-a-feminist-superhero/

Flood, A. (2013, February 18). Comic-book superheroine Cat aims to see off gender stereotypes. Retrieved from https: / /www.theguardian.com/ books/2013/feb/18/comic-book-superheroine-cat-gender?C$\mathrm{MP}=$ twt $\_\mathrm{gu}$

Ford, N. (2014, June 19). My So-Called Secret Identity: An interview with Will Brooker. Retrieved from http://sequart.org/magazine/46306/ will-brooker-interview/

Gani, A. (2015, August 18). Ch-ch-ch-changes: Academic to spend year as David Bowie's many personas. Retrieved from https://www. theguardian.com/music/2015/aug/18/ch-ch-ch-changes-academic-to-spend-year-as-david-bowies-many-personas 
Genette, G. (1997). Paratexts: Thresholds of interpretation (J. E. Lewin, Trans.). Cambridge: Cambridge University Press.

Granshaw, L. (2014, January 2). 'My So-Called Secret Identity' will change your view on women in comics. Retrieved from https://www.dailydot.com/upstream/my-so-called-secret-identity-female-herowilliam-brooker/

Gray, J. (2006). Watching with the Simpsons: Television, parody and intertexuality. New York, NY: Routledge.

Gray, J. (2010). Show sold separately: Promos, spoilers and other media paratexts. New York, NY: New York University Press.

Helvie, F. (2013). My So-Called Secret Identity - A superhero comic that breaks the so-called norms. Retrieved from http://sequart.org/magazine $/ 36875 /$ my-so-called-secret-identity-a-superhero-comicthat-breaks-the-so-called-norms/

Hills, M. (2015). Veronica Mars, fandom, and the "Affective Economics" of crowdfunding poachers. In L. Bennett, B. Chin, \& B. Jones (Eds.), Crowdfunding the future: Media industries, ethics, and digital society (pp. 183-197). Oxford: Peter Lang.

Hellekson, K. (2009). A fannish field of value: Online fan gift culture. Cinema Journal, 48(4), 113-118. http://dx.doi.org/10.1353/cj.0.0140

Hellekson, K., \& Busse, K. (2006). Fan fiction and fan communities in the age of the Internet: New essays. Jefferson: McFarland.

Hyde, L. (1983). The gift: Imagination and the erotic life of property. New York, NY: Vintage.

Issue 1, Page 13 [Online image]. Retrieved from http://www.mysocalledsecretidentity.com/comic/volume1/issue1/page13 
Jenkins, H. (1992). Textual poachers. London: Routledge.

Jenkins, H., Ford, S., \& Green, J. (2013). Spreadable media: Creating value and meaning in a networked culture. New York and London: New York University Press.

Johnson, D. (2013). Media franchising. Creative license and collaboration in the culture industries. New York, NY: New York University Press.

Jones, B., \& Bennett, L. (2013). Blurring boundaries, crossing divides: An interview with Will Brooker. Participations Journal of Audience \& Reception Studies, 10(1), 335-350.

Jones, B. (2014). Fifty shades of exploitation: Fan labor and Fifty Shades of Grey. Transformative Works and Cultures, 15. http://dx.doi. org/10.3983/twc.2014.0501

Jones, B. (2016). 'I hate Beyoncé and I don't care who knows it': Towards an ethics of studying anti-fandom. Journal of Fandom Studies, 4(3), 283-299.

Klinger, B. (1989). Digressions at the cinema: Reception and mass culture. Cinema Journal, 28(4), 3-18.

Kroese, E. (2013, February 23). Rant about My So-called Secret Identity. Retrieved from http://elsakroese.deviantart.com/journal/Rantabout-My-So-called-secret-Identity-355940165

Langsdale, S. (2013a, February 18). Will Brooker and the launch of My SoCalled Secret Identity. Retrieved from http://wegeekedthis.com/ will-brooker-and-the-launch-of-my-so-called-secret-identity/

Langsdale, S. (2013b, February 8). My So-Called Secret Identity: The one we've been waitingfor. Retrieved from http://wegeekedthis.com/my-socalled-secret-identity-the-one-weve-been-waiting-for/ 
Lazar, M.M. (2009). Entitled to consume: Postfeminist femininity and a culture of post-critique. Discourse \& Communication, 3(4), 371-400.

Lookbook [Online image]. Retrieved from http://www.mysocalledsecretidentity.com/lookbookLotz, A. D. (2007). The television will be revolutionized. New York, NY: New York University Press.

Markham, A., \& Buchanan, E. (2012). Ethical decision-making and internet research: Recommendations from the AoIR Ethics Working Committee (version 2.0).Retrieved from http://aoir.org/reports/ethics2.pdf

McRobbie, A. (2007). Postfeminism and popular culture: Bridget Jones and the new gender regime. In Y. Tasker \& D. Negra (Eds.), Interrogating Postfeminism (pp. 27-39). Durham, NC: Duke University Press.

Mittell, J. (2010, July 29). On disliking Mad Men [Blog Post]. Retrieved from https://justtv.wordpress.com/2010/07/29/on-dislikingmad-men/

Mittell, J. (2013, March 15). Veronica Mars and the exchanges of value revisited [Blog Post]. Retrieved from http://justtv.wordpress. com/2013/03/15/veronica-mars-and-exchanges-of-value-revisited/

Mittell, J. (2014). Serial orientations. Paratexts and contemporary complex television. In J. Eckel, B. leiendecker, D. Olek, \& C. Piepiorka (Eds.), (Dis)orienting media and narrative mazes (pp. 165-182). Bielefeld: Transcript Verlag.

Reviews. (n. d.). Retrieved from http://www.mysocalledsecretidentity. com/reviews

Backstory. (n. d.). Retrieved from http://mysocalledsecretidentity.com/ backstory

Parkin, S. (2014, October 17). Gamergate: A scandal erupts in the video-game community. The New Yorker. Retrieved from http://www. 
newyorker.com/tech/elements/gamergate-scandal-erupts-video-game-community

Proctor, W. (2013). "Holy crap! More Star Wars? More Star Wars? What if they're crap?" Disney, Lucasfilm and online Star Wars fandom in the 21st century. Participations: Journal of Audience and Reception Studies, 10(1), 198-224.

Roddy, K., Carlen L., \& Suzanne, S. (2013). Toward a feminist superhero: An interview with Will Brooker, Sarah Zaidan, and Suze Shore. Transformative Works and Cultures, 13. Retrieved from http://journal. transformativeworks.org/index.php/twc/article/view/476/362

Sarkeesian, A. (2012). Tropes vs. women in video games. Retrieved from https: / /www.kickstarter.com/projects/566429325/tropes-vswomen-in-video-games

Scott, S. (2010). The trouble with transmediation: Fandom's negotiation of transmedia storytelling systems. Translating Media, 30(1), 30-34.

Scott, S. (2013). Fangirls in refrigerators: The politics of (in)visibility in comic book culture. Transformative Works and Cultures, 13, Retrieved from http://journal.transformativeworks.org/index.php/ twc/article/view/460/384

Scott, S. (2015a). The moral economy of crowdfunding and the transformative capacity of fan-ancing. New Media \& Society, 17(2), 167-182.

Scott, S. (2015b). From poaching to pinning: geek girl(y) culture on Pinterest, paper presented at Console-ing Passions International Conference, Dublin, 2015.

Scott, S. (2015c). 'Cosplay is serious business': Gendering material fan labor on Heroes of Cosplay. Cinema Journal, 54(3), 146-154. 
Sneddon, L. (2013, June 3). Re: Interview: Will Brooker on My So-Called Secret Identity, a new kind of superhero comic [Blog post]. Retrieved from http://comicsbeat.com/interview-will-brooker-onmy-so-called-secret-identity-a-new-kind-of-superhero-comic/

Taylor, A. (2014). "Avengers dissemble! Transmedia superhero franchises and cultic management. Journal of Adaptation in Film \& Performance, 7(2), 181-194.

theviciouspixie. (2013, February 24). Re: Not the only good thing: Clouds reviews My So-Called Secret Identity [Blog post]. Retrieved from http://theviciouspixie.blogspot.co.uk/2013/02/not-only-goodthing-clouds-reviews-my.html

Thomas, R. (2013). The Veronica Mars movie project. Retrieved from https://www.kickstarter.com/projects/559914737/the-veronica-mars-movie-project

Vitali-Rosati, M. (2014). Digital paratext, editorialization, and the very death of the author. In N. Desrochers \& D. Apollon (Eds.), Examining paratextual theory and its applications in digital culture (pp. 110-127). Hershey, PA: Information Science Reference. 